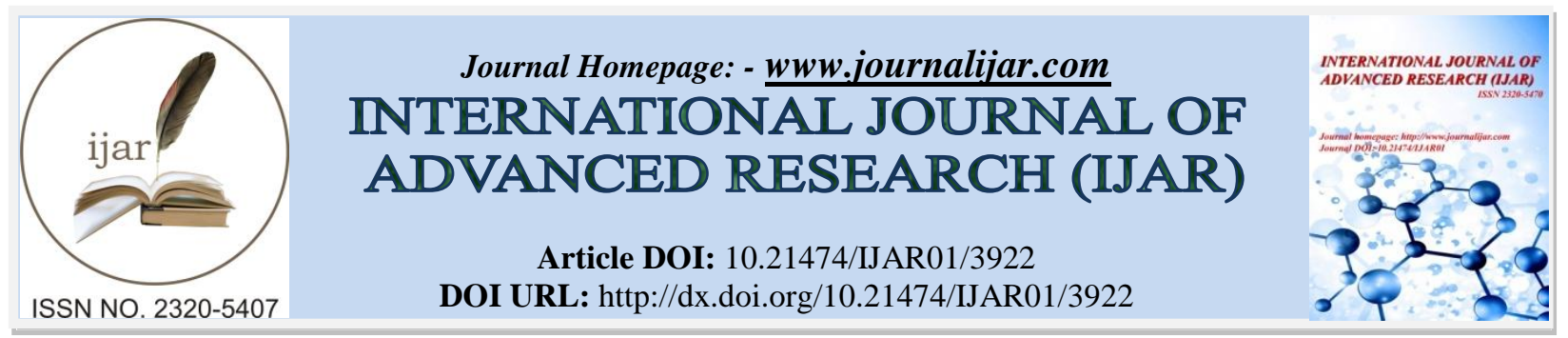

RESEARCH ARTICLE

\title{
ASSESSMENT OF CRIME AGAINST WOMEN OCCURRED IN SEASONS OF DARJEELING DISTRICT.
}

Gopal Prasad.

Ph. D Scholar, Department of Geography, Faculty of Natural Sciences, Jamia Millia Islamia, New Delhi, India.

\section{Manuscript Info}

Manuscript History

Received: 14 February 2017

Final Accepted: 18 March 2017

Published: April 2017

Key words:-

Women, Crime, Season, Time-cycle, Victims age.

\section{Abstract}

Crime has become a serious concern for everyone living in the society in the modern time (Zenelaj.et.al 2013).As per NCRB, any crime specifically committed against women is characterised as 'crimes against women'. In this paper an attempt has been made to know the spatial variation of crimes against women occurring in four seasons of the study area, Darjeeling. Analysis and findings were based on secondary data collected from Superintendent of Police office, and Siliguri Police Commissionerate office, Siliguri, Darjeeling. Among the four seasons maximum crime against women was committed during Monsoon (37.12) per cent followed by Summer (26.05) per cent, Winter (20.22) per cent, and Autumn (16.62) per cent. Highest incidences of torture (41.65) per cent, rape (37.06) per cent, molestation (34.93) per cent, kidnapping \& abduction (33.97) per cent took place in Rainy season. The victims of molestation and kidnapping $\&$ abduction were mostly convicted between the time-cycle of 16-20hrs in all four seasons and rape victims were victimized during 12-16hrs in summer and winter season and during 16-20hrs in autumn and winter seasons. The victims of molestation mostly victimized were from the ages between 6-30 years, victims of kidnapped $\&$ abducted were from $6-18$ years and rape victims were from the age between below 10yrs to 18 yrs.

Copy Right, IJAR, 2017,. All rights reserved.

\section{Introduction:-}

Crime has become a serious concern for everyone living in the society in the modern time (Zenelaj.et.al 2013). Although women occupy a central position in shaping the society as a first teacher of children they are more vulnerable to crime (Chauhan et.al 2016). Any crime specifically committed against women is characterized as 'crimes against women' (NCRB). The type of crime against women occurred in the Darjeeling district during (20042014) were Torture (498A IPC), Molestation (354 IPC), Kidnapping \& Abduction (363-373 IPC), Rape (376 IPC), Eve-teasing (509 IPC), Homicide for Dowry, Dowry deaths (302/304-B IPC), Immoral Traffic (Prevention) Act, 1956 (ITP Act SLL) and Indecent Representation of women (Prohibition) Act, 1986 (IRW SLL).

\section{Objectives:-}

* To analyse the type of crime against women in Darjeeling

* To assess the seasonal pattern of crime against women in Darjeeling

Corresponding Author:- Gopal Prasad.

Address:- Ph. D Scholar, Department of Geography, Faculty of Natural Sciences, Jamia Millia Islamia, New Delhi, India. 


\section{Database and Methodology:-}

This paper is based on secondary data sourced from Superintendent of Police office, Darjeeling and Siliguri Police Commissionerate office, Siliguri. The data obtained from the concerned offices were from $(2004-2014)$. Further the data has been processed in Microsoft excel for graphical representation. Data is classified into four seasons. Agegroups of rape victims is referenced from National Crime Records Bureau (NCRB), and its time-cycle is consulted from Ph.D thesis by Singh, A (1992).

\section{Study area:-}

This paper is written on about crimes against women in Darjeeling district. The district Darjeeling is located in the northern part of West Bengal comprising 12 CD Blocks sprawling across the terai and hilly tracts of the Himalaya regions. It extends from $26^{\circ} 31^{\prime}-27^{\circ} 13^{\prime}$ north latitude to $87^{\circ} 50^{\prime}-85^{\circ} 53^{\prime}$ east longitude. The district occupies an area of 3,149 square kilometers stretching from boundaries of Sikkim in North to Bangladesh and West Dinajpur in South and Nepal, Bihar in the West to

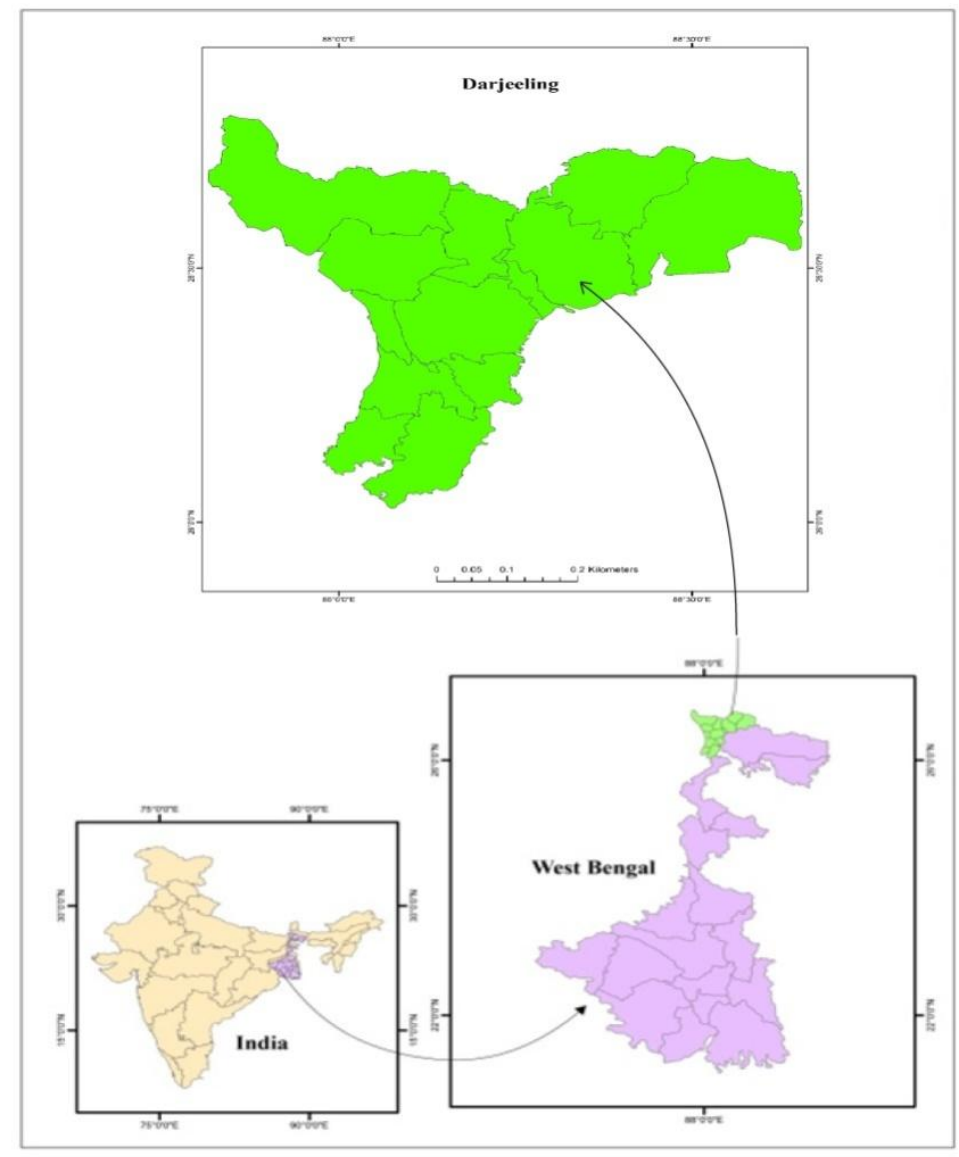

Fig 1:-

Bhutan, Jalpaiguri in the East. The district is full of dense forests and hilly tracts of land. Demography details based on Census 2011 includes the total population of 1,842,034 shared by male population of 934,796 and female 907,238 populations. Its density is 585 person per square kilometer. It has a sex-ratio of 971 females per every 1000 males. The literacy rate of district is 79.92 per cent. Among the total literates of district, 85.94 per cent literates are male and 73.7 per cent are female.

\section{Literature Review:-}

According to Rao (1967), in India every seven minutes some crime is committed against women in the country, every fifty six minutes a women is raped, every twenty six minutes one is molested, every thirty three minutes some criminality is perpetrated against her and every one hour and forty two minutes a dowry death takes place.Geography of crime involves interest in spatial structure in environmental associations and in the special 
qualities of place (Herbert 1989)In general it is observed that there doesn't exist any scientific evidence that leads to cause crime, but some of the experts are able to find out the strong correlation between the rising temperature and increasing crime (Envisage Technologies, 2014). Harries (1980) in his study on Crime and Environment have discussed on the relationship between the human, physical environment and criminal behavior. He focused on seasonal crime and climate relationship based on the influences of weather. Anderson (1987) confirmed in his study that violent crimes - including murder, rape and assault was high during hotter quarters and years and the link between temperature and crime was stronger than the nonviolent crime. Ransom (2014) in his study "Crime, weather, and climate change." revealed rising temperatures causing due to climate change may add 180,000 cases of rape between 2010 and 2099 in USA. In article 'Climate and Crime' by Mishra, A. (2014), done on Allahabad city of Uttar Pradesh found linear association of temperature with crime. He also argued the rate of crime increases with rise in temperature.

\section{Discussions and result:-}

Fig.No.2:- Type of Crime against women occurred in Darjeeling district (2004-2014).

\section{Type of Crime against women occured in Darjeeling district (2004-2014)}

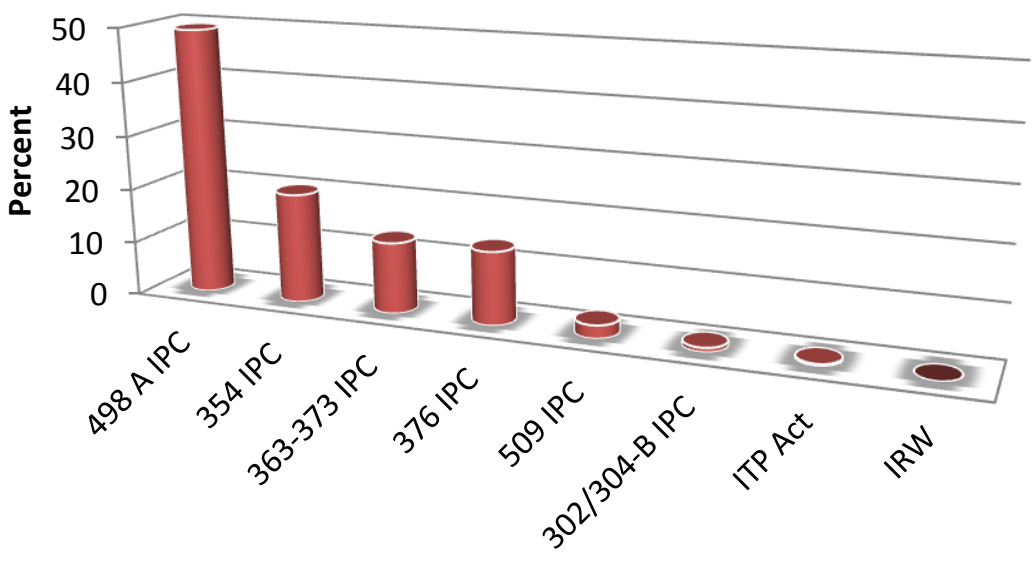

Crime

Type of crime

Source: Compiled by Author from Superintendent of Police office, Darjeeling \&Siliguri Police Commissionerate office, Siliguri

The figure (2) above shows the details of type of crime against women committed during the tenure of 11 years (2004-2014) in Darjeeling district of West Bengal state. The stacks of different height reflect the information of variation of incidences occurred against women. The incidences faced by women are Torture (498 A IPC), Molestation (354 IPC), Kidnapping \& Abduction (363-373 IPC), Rape (376 IPC), Eve-teasing (509 IPC), Homicide for Dowry, Dowry Deaths or their attempts (302/304-B IPC), Immoral Traffic (Prevention) Act, 1956 (SLL) and Indecent Representation of women (Prohibition) Act, 1986 (SLL). Out of total crime against women in Darjeeling, crime Torture was the highest (49.38) per cent. The other type of crime that occurred with women was Molestation (20.29) per cent, Kidnapping \& Abduction (13.15) per cent, Rape (13.54) per cent, Homicide for Dowry, Dowry deaths or their attempts (0.782) per cent, Immoral Traffic (Prevention) Act, 1956 (SLL) (0.409) per cent and Indecent Representation of women (Prohibition) Act, 1986 (SLL) (0.0186) per cent respectively. All such crimes were occurred at different time and month of the year which is further analysed as seasonal pattern of crime against women in Darjeeling district. 
Seasonal pattern of crime against women, Darjeeling (2004-2014):-

Fig.No.3:- Crime against women in Seasons, Darjeeling (2004-2014).

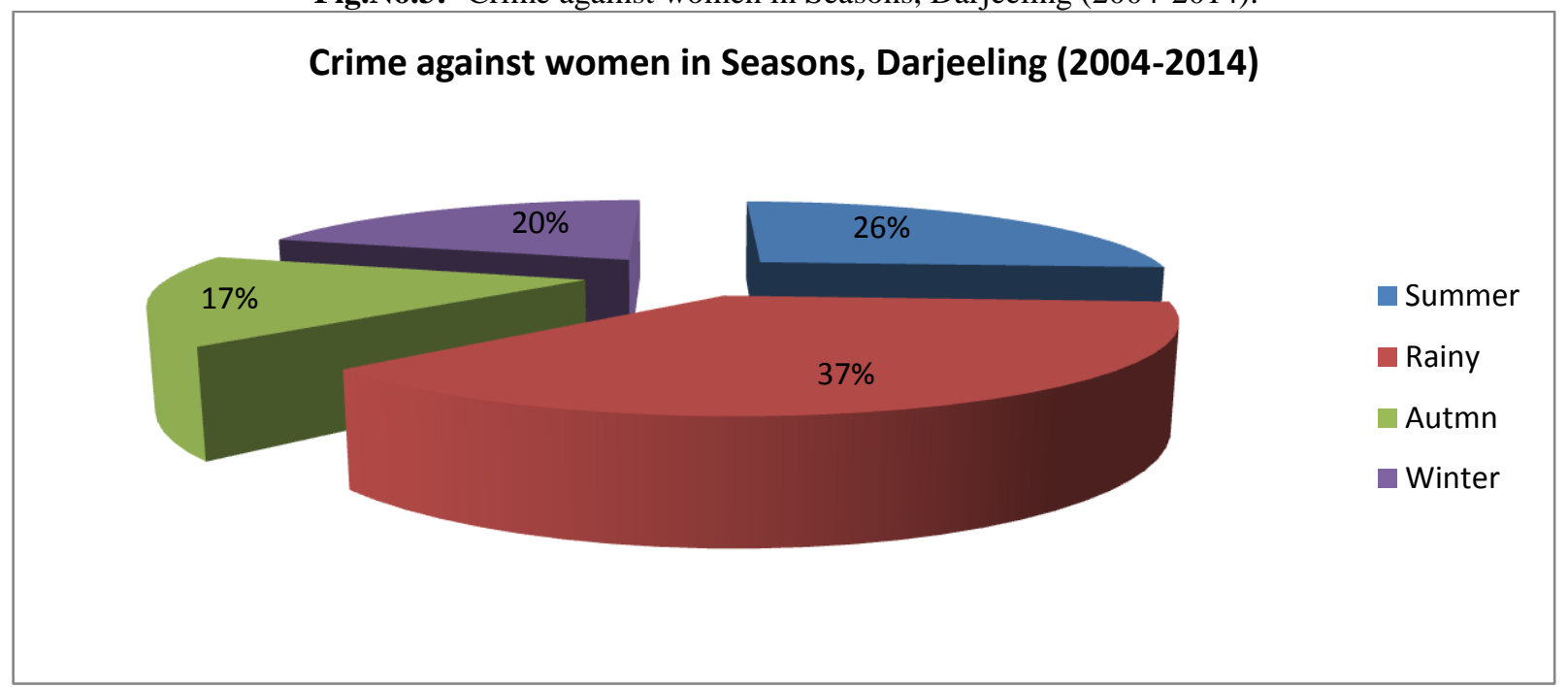

Source: Compiled by Author from Superintendent of Police office, Darjeeling \&Siliguri Police Commissionerate office, Siliguri

The crime against women all that occurred in different time and month of the year are accordingly organised in seasons for further analysis. The above given pie chart reflects the detail of crime against women committed in seasons during the period of (2004- 2014) in Darjeeling district. The pie chart shows that the maximum incidences of crime against women occurred during Rainy season (37) per cent and it was followed by Summer season (26) per cent, Winter season (20) per cent and Autumn season (17) per cent respectively (Fig. 3).

Fig No 4:- Type of Crime against women in seasons, Darjeeling (2004-2014).

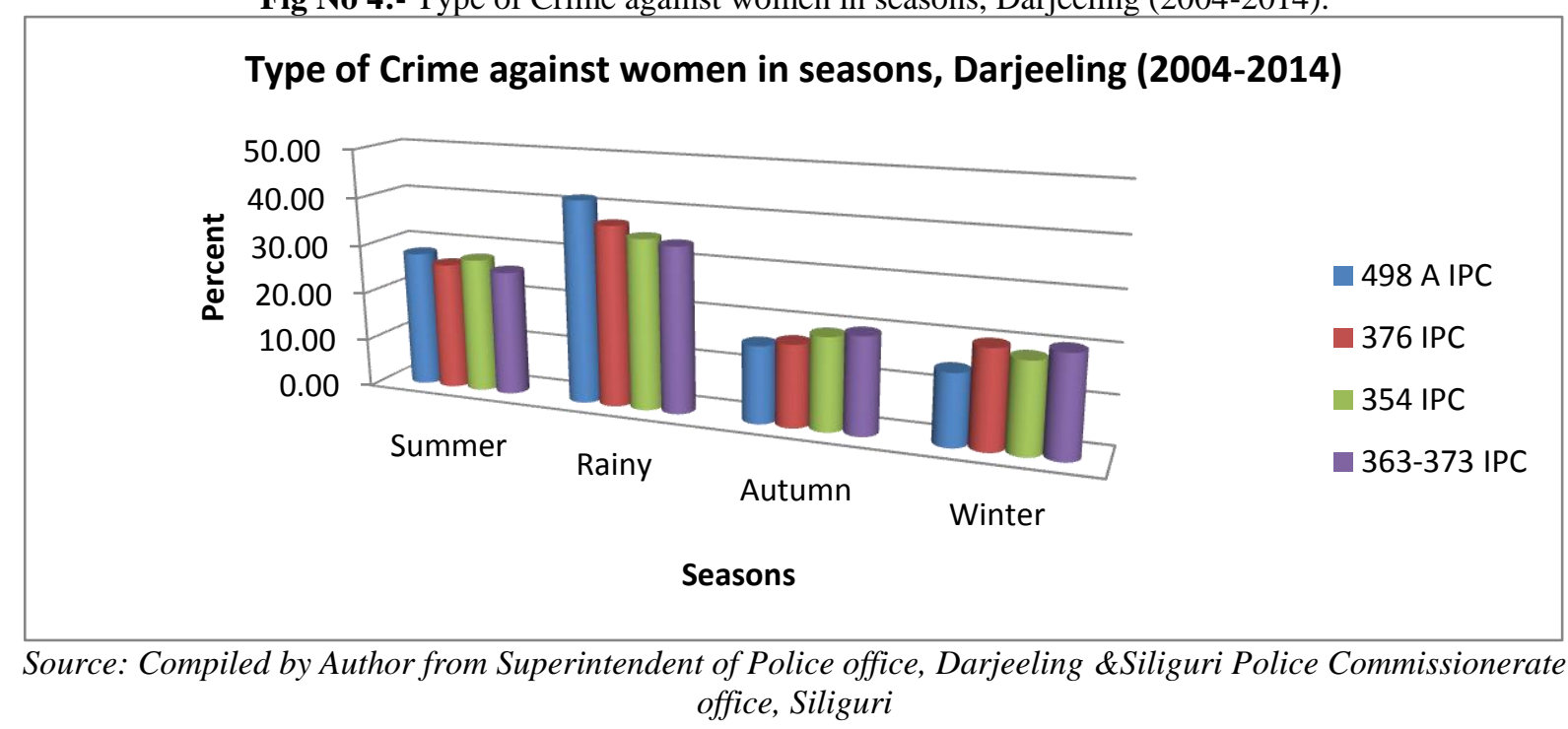

The crime against women occurred throughout the year but they varied from season to season when they were accounted accordingly. As per the evidence of monthly statements reported in the police stations of Darjeeling the percentage of crime differed from one month to another month. So, thus the type of crime that occurred with women varied in seasons. Like the crime Torture against women mostly occurred during Rainy season (41.65) per cent and then in Summer season (28.00) per cent, in Autumn (15.77) per cent and in Winter (14.58) per cent. Similarly, highest cases of rape took place in Rainy season (37.06) per cent and decreased to (26.16) per cent during Summer season, (20.03) per cent during Winter and (16.76) per cent in Autumn season. The incidences of molestation was high during Rainy season (34.93) per cent and it was followed by Summer season (27.70) per cent, Autumn season 
(18.97) per cent and (18.40) per cent in Winter season. The kidnapping \& abduction cases came up more during Rainy season (33.97) per cent, during Summer season (25.66) per cent, during Winter season (20.55) per cent and (19.83) per cent during Autumn season. Overall, it is identified that all type of crime against women was high during Rainy season (see fig 4).

Fig No 5:- Time-cycle of Crime against women in Summer season, Darjeeling (2004-2014)

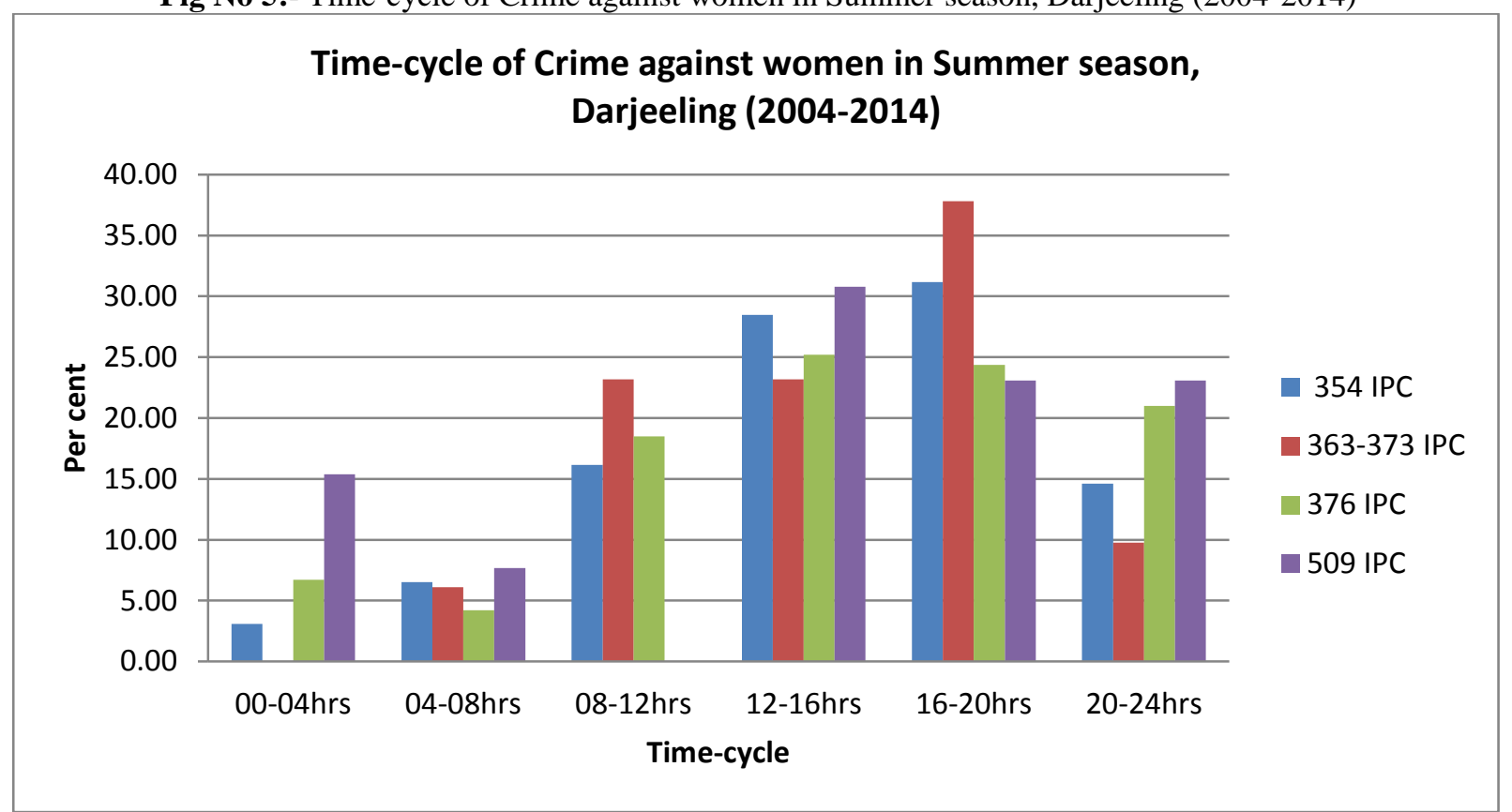

Source: Compiled by Author from Superintendent of Police office, Darjeeling \& Siliguri Police Commissionerate office, Siliguri

Incidences occurred at particular time as it was mentioned in the reports registered in the police stations of the district. The above bar graph shows the percentages of crime against women that occurred in different time-cycle during summer season. The figure illustrates the most happening hours of crime. The time between $08 \mathrm{hrs}$ to $24 \mathrm{hrs}$ is the peak time for the offenders to meet their prey or targets. It is noted above (20) per cent all type of crime against women occurred between the time-cycle of 12-16hrs and 16-20hrs. It seems the duration is very conducive for the accused to convict their victims. In duration of whole $24 \mathrm{hrs}$ maximum number of victims of molestation were convicted between the time-cycle of 16-20hrs (31.15) per cent, then (28.46) per cent during 12-16hrs, then (16.15) per cent during 08-12hrs, (14.62) per cent between 20-24hrs and below (6.54) per cent between 00-08hrs. The large number of victims were kidnapped \& abducted during the time-cycle of 16-20hrs (37.80) per cent, (23.17) per cent between 08-12hrs and 12-16hrs, (9.76) per cent between 20-24hrs and below (6.10) per cent between 00-08hrs. The victims of rape were highly convicted between 12-16hrs (25.21) per cent, (24.37) per cent during 16-20hrs, (21.01) per cent between 20-24hrs, (18.49) per cent between 08-12hrs and below (6.72) per cent between 00-08hrs. The cases of eve-teasing were more during 12-16hrs (30.77) per cent, (23.08) per cent between 16-20hrs and 20-24hrs, (15.38) per cent during 00-04hrs and (7.69) per cent between 04-08hrs (fig. 5). 
Fig No. 6:- Time-cycle of Crime against women in Rainy season, Darjeeling (2004-2014)

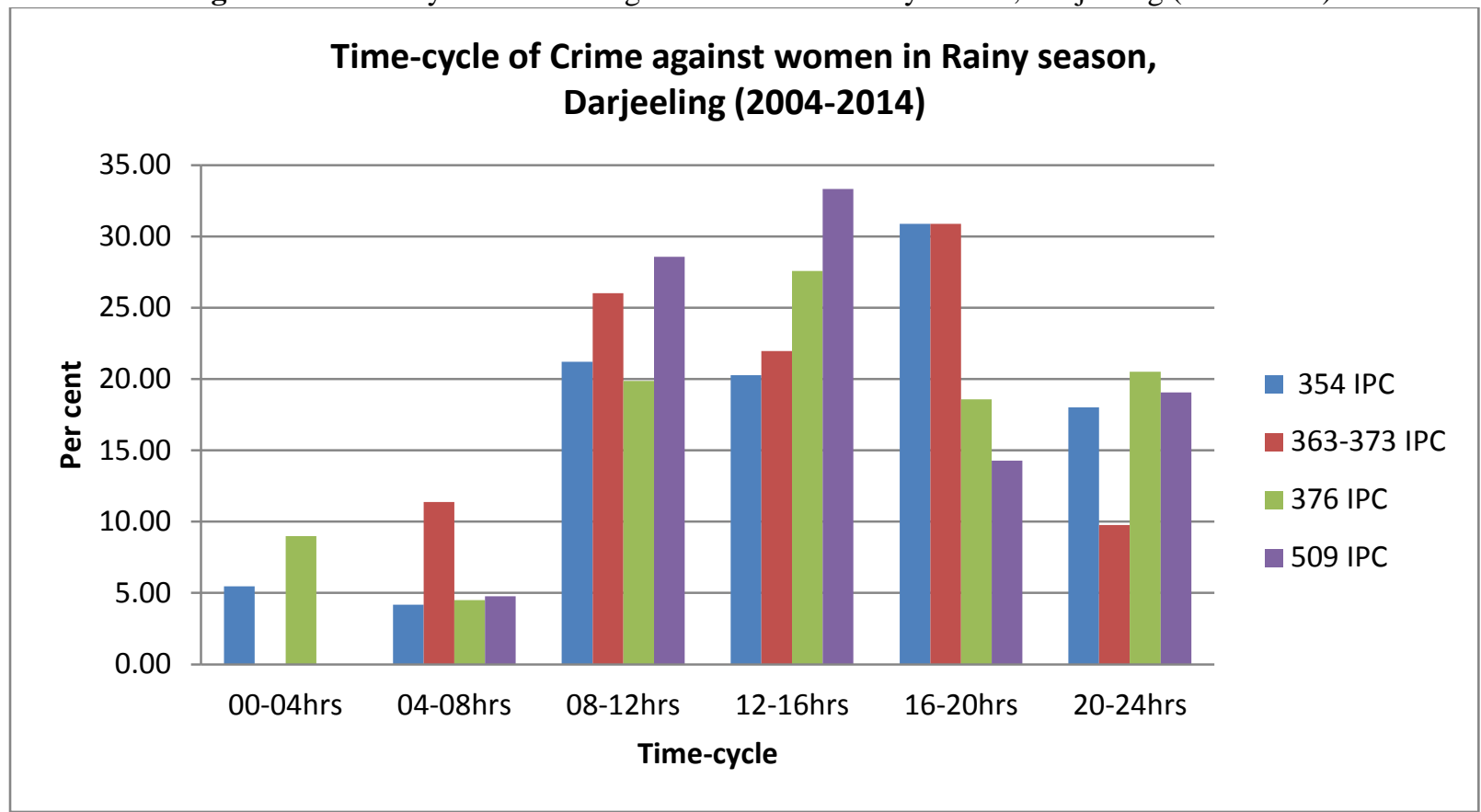

Source: Compiled by Author from Superintendent of Police office, Darjeeling \&Siliguri Police Commissionerate office, Siliguri

The figure above illustrates the details of crime against women occurred in different time-cycle of day during rainy/monsoon seasons. During whole $24 \mathrm{hrs}$ of day the maximum number of victims was convicted between $08 \mathrm{hrs}$ to $24 \mathrm{hrs}$. Between $08 \mathrm{hrs}-20 \mathrm{hrs}$ more than 20 per cent of victims were victimized. In duration of whole $24 \mathrm{hrs}(30.87)$ per cent of victims of molestation was convicted between 16-20hrs, (21.22) per cent during 08-12hrs, (20.26) per cent between 12-16hrs, (18.01) per cent during 20-24hrs and below (5.47) per cent between 00-08hrs. (30.89) per cent of victims were kidnapped \& abducted during 16-20hrs, (26.02) per cent during 08-12hrs, (21.95) per cent between 12-16hrs, (11.38) per cent during 04-08hrs and below (9.76) per cent of victims were kidnapped \& abducted between 24-04hrs. The highest per cent of rape victims were victimized during 12-16hrs that is (27.56) per cent. During 20-24hrs (20.51) per cent of victims were raped, between 08-12hrs (19.87) per cent of rape victims were convicted, (18.59) per cent of victims were victimized during 16-20hrs and below (8.97) per cent victims were convicted between 00-08hrs. The eve-teasing cases were more during 12-16hrs (33.33) per cent. During 08-12hrs (28.57) per cent victims were eve-teased by the accused, (19.05) per cent during 20-24hrs, (14.29) per cent between 16-20hrs and (4.76) per cent of victims were convicted during 04-08hrs (fig.6). 
Fig No 7:- Time-cycle of Crime against women in Autumn season, Darjeeling (2004-2014)

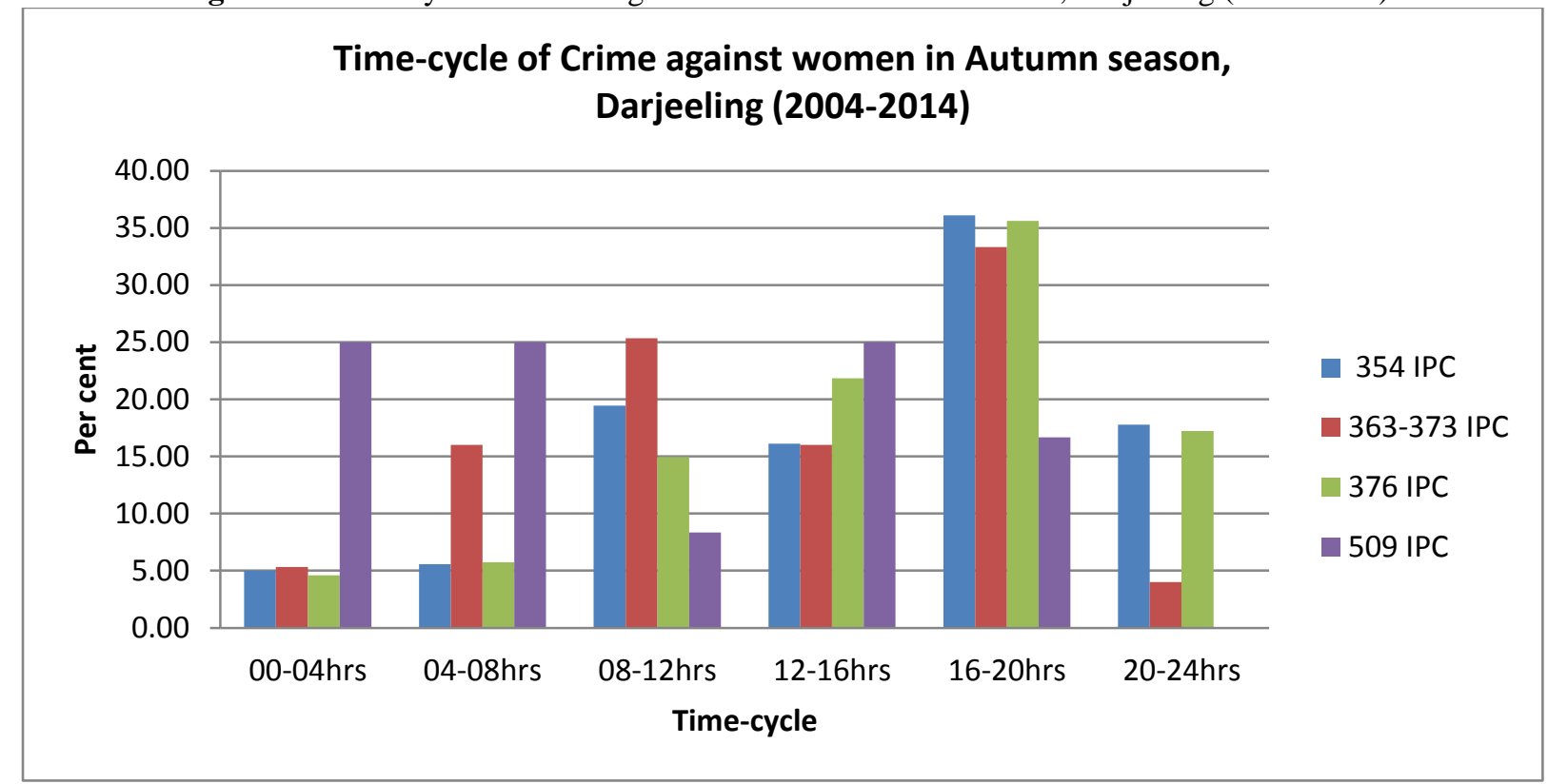

Source: Compiled by Author from Superintendent of Police office, Darjeeling \&Siliguri Police Commissionerate office, Siliguri

The number of incidences against women that occurred during different time-cycle in Autumn season is illustrated in the figure above. Maximum number of molestation of victims was convicted during 16-20hrs (36.11) per cent, (19.44) per cent in 08-12hrs, (17.78) per cent during 20-24hrs, (16.11) per cent in 12-16hrs and below (5.56) per cent between 00-08hrs. The large number of victims (33.33) per cent were kidnapped \& abducted during 16-20hrs, (25.33) per cent in 08-12hrs, (16.00) per cent between 04-08hrs and 12-16hrs and below (5.33) per cent between 0004hrs and 20-24hrs. During this season between 16-20hrs (35.63) per cent of rape victims were convicted, (21.84) per cent during 12-16hrs, (17.24) per cent between 20-24hrs, (14.94) per cent during 08-12hrs and below (5.75) per cent occurred at the time of 00-08hrs. The eve-teasing cases were more (25) per cent during 00-04hrs, 04-08hrs, and 12-16hrs. Between 16-20hrs (16.67) per cent of victims were eve-teased and (8.33) per cent during 08-12hrs (fig.7) 
Fig No.8:- Time-cycle of Crime against women in Winter season, Darjeeling (2004-2014)

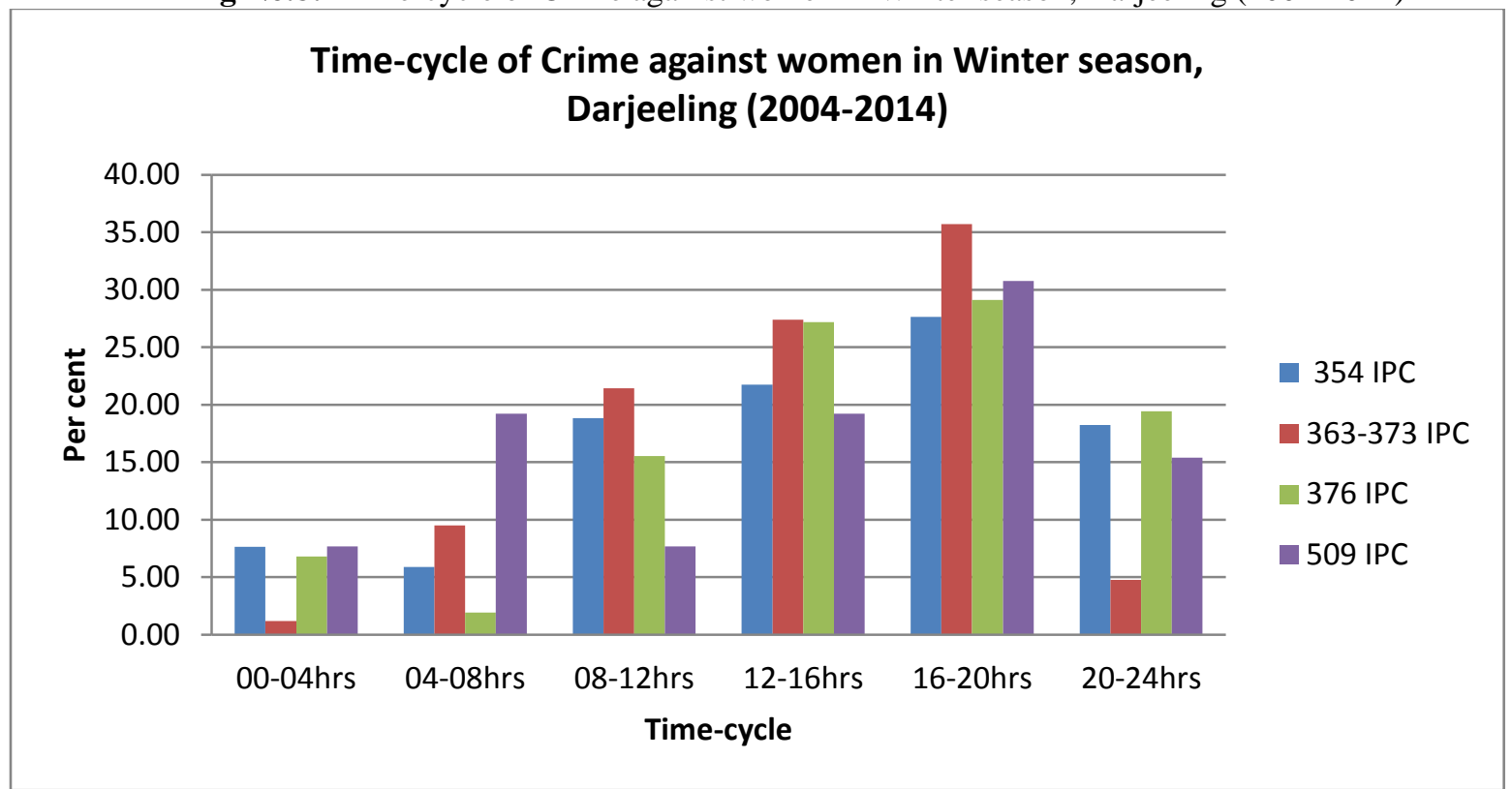

Source: Compiled by Author from Superintendent of Police office, Darjeeling \&Siliguri Police Commissionerate office, Siliguri

During winter season the incidences of crime against women above 20 per cent occurred between 12-16hrs and 1620hrs. The highest cases of molestation occurred between 16-20hrs (27.65) per cent. (21.76) per cent molestation cases occurred between 12-16hrs, (18.82) per cent during 08-12hrs, (18.24) per cent between 20-24hrs and below (7.65) per cent of cases during 00-08hrs. Kidnapping \& abduction cases were high (35.71) per cent during 16-20hrs, (27.38) per cent during 12-16hrs, (21.43) per cent between 08-12hrs and below (9.52) per cent during the time-cycle of 04-08hrs, 20-24hrs and 00-04hrs. (29.13) per cent rape victims were victimized at the time cycle of 16-20hrs, (27.18) per cent during 12-16hrs, (19.42) per cent at 20-24hrs, (15.53) per cent between 08-12hrs and below (6.80) per cent during 00-08hrs. The cases of eve-teasing victims (30.77) per cent were convicted during 16-20hrs. (19.23) per cent of victims were convicted between 04-08hrs and 12-16hrs, (15.38) per cent of victims victimized during 20$24 \mathrm{hrs}$ and (7.69) per cent victims convicted during 00-04hrs and 08-12hrs (fig 8)

\begin{tabular}{|c|c|c|c|c|c|c|}
\hline \multicolumn{6}{|c|}{ Table no. 1: Age wise rape victims of Darjeeling, (2004-2014) } \\
\hline Age & $00-10 \mathrm{yrs}$ & $11-14 \mathrm{yrs}$ & $15-18 \mathrm{yrs}$ & $19-30 \mathrm{yrs}$ & $31-50 \mathrm{yrs}$ & $50+$ \\
\hline Rape & 35.26 & 27.36 & 24.47 & 9.83 & 2.31 & 0.77 \\
\hline
\end{tabular}

A victim of incidences against women belongs to following age groups. Among the age groups of rape victims, the victims below the age of $10 \mathrm{yrs}$ to $18 \mathrm{yrs}$ were highly subjected to rape. From the different age groups of victims, the victims of age group below 10yrs are high (35.26) per cent. Victims between the age group of 11-14yrs accounted to (27.36) per cent, 15-18yrs accounted to (24.47) per cent and victims above age group 19yrs accounted to below (10) per cent (table 1).

Table no. 2: Age wise victims of molestation and kidnapping \& abduction, Darjeeling (2004-2014)

\begin{tabular}{|l|c|c|c|c|c|c|c|c|}
\hline \multicolumn{1}{|c|}{ Age } & $00-6 \mathrm{yrs}$ & $6-12 \mathrm{yrs}$ & $12-16 \mathrm{yrs}$ & $16-18 \mathrm{yrs}$ & $18-30 \mathrm{yrs}$ & $30-45 \mathrm{yrs}$ & $45-60 \mathrm{yrs}$ & $60+$ \\
\hline Kidnapping \& Abduction & 0.86 & 11.58 & 53.69 & 24.75 & 9.24 & 1.72 & 0.00 & 0.12 \\
\hline Molestation & 7.75 & 29.58 & 38.73 & 9.15 & 19.72 & 4.23 & 0.70 & 0.00 \\
\hline
\end{tabular}

The victims between the age group of 6-18yrs are highly prone to kidnapping $\&$ abduction. (53.69) per cent victims of age group 12-16yrs are been kidnapped \& abducted by the offenders. Victims between the ages of 6-30yrs are highly prone to molestation. Maximum (38.73) per cent victims of molestation belongs to age group of 12-16yrs and (29.58) per cent

to 6-12yrs (table 2). 


\section{Conclusions:-}

- The maximum crime against women among all the crime was torture (49.38) per cent.

- Maximum incidences of crime against women occurred during Rainy season (37) per cent.

- Highest incidences of torture (41.65) per cent, rape (37.06) per cent, molestation (34.93) per cent, kidnapping \& abduction (33.97) per cent took place in Rainy season.

- In Summer maximum number of victims of molestation were convicted between the time-cycle of 16-20hrs (31.15) per cent, (37.80) per cent victims were kidnapped \& abducted during the time-cycleof16-20hrs, rape victims between 12-16hrs (25.21) per cent and cases of eve-teasing were more during 12-16hrs (30.77) per cent.

- In Rainy season maximum cases of molestation occurred between 16-20hrs (30.87) per cent, (30.89) per cent of victims kidnapped \& abducted during 16-20hrs, rape victims (27.56) per cent between 12-16hrs and eve-teasing victims (33.33) per cent during 12-16hrs.

- In Autumn season maximum cases of molestation occurred between 16-20hrs (36.11) per cent, (33.33) per cent of victims kidnapped \& abducted during 16-20hrs, rape victims (35.63) per cent between 16-20hrs and eveteasing victims (25) per cent during 00-04hrs, 04-08hrs and 12-16hrs.

- In Winter season maximum cases of molestation occurred between 16-20hrs (27.65) per cent, (35.71) per cent of victims kidnapped \& abducted during 16-20hrs, rape victims (29.13) per cent between 16-20hrs and eveteasing victims (30.77) per cent during 16-20hrs.

- The victims between below the age of $10 \mathrm{yrs}$ to $18 \mathrm{yrs}$ were highly subjected to rape. The victims between the age group of 6-18yrs are highly prone to kidnapping \& abduction. Victims between the ages of 6-30yrs were highly prone to molestation.

\section{Acknowledgements:-}

This research paper is a part of my Ph.D research, department of geography, Jamia Millia Islamia, New Delhi. I am very much thankful to Prof. Mary Tahir and the Department of Geography, Jamia Millia Islamia for providing me resources and facilities for the purpose of carrying out my research work.

\section{References:-}

1. Mishra, A. (2014); Climate and Crime; Global Journal of Science Frontier Research: H Environment \& earth Science; vol.14 Issue 6 Version 1.0 Year 2014.

2. Chauhan, R. and Baraik, V.K. (2016); Mapping Crime against Women in India: Spatio-Temporal Analysis, 2001-2012; World Academy of Science, Engineering and Technology International journal of Law and Forensic Sciences; Vol:3, No.6, 2016.

3. Zenelaj, Engjellushe. Elezi, Myzafer.(2013); "The geography of crime in Albania 2000-2012", The Macrotheme Review A multidisciplinary journal of global macro trends, Ismail Qemali Vlora University, Albania.

4. Ranson, Matthew (2014) "Crime, weather, and climate change." Journal of Environmental Economics and Management, Volume 67, Issue 3, Pages 274-302 Feb. 2014.

5. Anderson, Craig A. (1987) "Temperature and aggression: Effects on quarterly, yearly, and city rates of violent and nonviolent crime." Journal of Personality and Social Psychology,52(6):1161-73.

6. Envisage Technologies "Climate and crime: How temperature change could impact future law enforcement." www.envisagenow.com/climate-and-crime, 20 August 2014.

7. Singh, Abhe (1992); crimes in Haryana A Spatio-Temporal Analysis (1966-85); Ph.D Thesis; Jamia Millia Islamia, New Delhi.

8. Harries, K.D. (1980); Crime and the Environment; National Criminal Justice Reference Service (NCJRS); Corporate Author: Charles C. Thomas United States of America. Page Count: 163.

9. National Crime Records Bureau, Ministry of Home Affairs. 